Vol. 11, n² | 2007

Varia

\title{
Whose crime? Arson, class warfare and traders in Nairobi, 1940-2000
}

Claire C. Robertson

\section{(2) OpenEdition \\ 1 Journals}

Electronic version

URL: https://journals.openedition.org/chs/109

DOI: $10.4000 /$ chs. 109

ISSN: 1663-4837

Publisher

Librairie Droz

Printed version

Date of publication: 1 December 2007

Number of pages: $25-47$

ISBN: 978-2-600-01224-9

ISSN: $1422-0857$

\section{Electronic reference}

Claire C. Robertson, "Whose crime? Arson, class warfare and traders in Nairobi, 1940-2000", Crime, Histoire \& Sociétés / Crime, History \& Societies [Online], Vol. 11, n² | 2007, Online since 01 March 2011, connection on 22 March 2022. URL: http://journals.openedition.org/chs/109 ; DOI: https://doi.org/ 10.4000/chs. 109

This text was automatically generated on 22 March 2022.

(c) Droz 


\title{
Whose crime? Arson, class warfare and traders in Nairobi, 1940-2000 ${ }^{1}$
}

\author{
Claire C. Robertson
}

In developed countries unlicensed sellers on the streets are summarily fined and/or arrested without public comment in most cases; most people earn their living in other ways. In developing countries street life includes ever more vendors, whose illegality has become a venue for government crime. In Kenya the struggle for existence pits poor traders against the propertied classes and their ally, the government. I will suggest here that arson is and was used against small-scale traders as a weapon of class warfare in an inversion of the usual stereotype that would have the poor burning the property of the rich as part of a revolution or out of resentment. In this case, repeatedly, under both colonial and independent Kenyan governments, the propertied classes have ruthlessly exercised the property crime of arson against those whose meager property often consists only of a ramshackle market stall and its contents.

But arson is only a part of the crime scene involving traders. The massive numbers of poor people make Western-style prohibition of urban street culture and economic activities almost impossible, but vested interests lobby for it relentlessly, while ordinary police try to turn the situation to their advantage. The result is that criminalization of ordinary traders' activities has made crime pervasive and inevitable. This essay looks at the evolution of the criminalization of small-scale trade, especially street-selling, in Nairobi from 1940 to 2000 to explore how stringent population control measures were first imposed by the British colonial government in an effort to suppress World War II era hawking, were then heightened during the 1950s Emergency, and then after independence in 1963 when hawker policy was transformed into an instrument for corruption. Arbitrary and sometimes violent population control measures were exercised first against hawkers in Nairobi in the 1940s, pioneering later Emergency policies that might have included market arsons. A question raised is, just whose crime was/is at issue in the continuing warfare waged against Nairobi traders, not only on the streets but also in markets? 
Crime in Nairobi is a large topic but not a new one; it has been called Nairobbery. There is, however, widespread agreement that crime has worsened significantly in recent years at every level - from petty street crime to large-scale government corruption with many stops between. Even large banks no longer guarantee the deposits of their customers due to widespread malfeasance by employees in connection with ATM cards. The post-Moi Kibaki government, elected on an anti-corruption pledge, still has many of the same notoriously corrupt personnel, who have perpetuated the relentless exploitation that so impoverishes most Kenyans. Policies sanctioned at the highest levels of government foster the institutionalization of crime in Nairobi with regard to the informal sector - both within the sector and outside of it enabled by those very policies.

4 In this essay I shall demonstrate that arson particularly characterized the periods of the 1950s, and the late 1990s to 2000, while the whole span is examined with particular attention to women traders, often the most vulnerable to inimical regulations. Even though it is bifurcated by the transition to independence in 1963, recent policy is as antithetical to small traders, or perhaps even more so, as British colonial policies were. I will look primarily at arson in connection with markets, controls on hawking as an occupation and on hawkers as persons, the politicization of hawker controls, and hawkers' resistance. I will suggest that the criminalization of the ordinary activities of traders in the informal sector by both the colonial and independent Kenyan governments, making it necessary for ever-growing numbers of people to contravene laws just to earn a living, has been accompanied by the criminalization of government, especially in connection with attempts to control the informal sector. Insofar as traders must contravene laws, just so far have certain government branches (not without internal conflicts), especially some of the police, contravened both laws and ethical standards not only to destroy trading premises and confiscate commodities, but also to extort, assault, rob and otherwise terrorize traders. And employed through it all, wielded by various interested parties, has been the most dreaded weapon of mass destruction for traders, arson. Nonetheless, while arson bookends the period examined and frames the experiences of many traders, it was not a constant but seems to represent extreme tensions within the highly stratified business sector and between poorer traders and government.

\section{The Great Gikomba Fire of 2000}

5 Early in the morning of 6 September 2000 a fire began in Kamukunji in eastern Nairobi at Gikomba Market, the largest market in Kenya, much of whose outdoor area is occupied semi-legally or illegally by thousands of small-scale retailers selling a wide variety of commodities. Two large storey buildings there housed much of Kenya's garment industry. Begun in the outdoor fish stalls, the fire spread rapidly, ultimately destroying most of the market in its eight- hour path of destruction. There were three fatalities among the sellers caused by the stress of losing everything; most sellers lost their livelihoods and the buildings, the legal part of the market, were destroyed.

What began this fire that dwarfed all others? The various explanations reflect their sources and the market's status as a multi-purpose site key to the lives of its population: a homeless children's campfire run amok; a food kiosk's cooking fire not properly damped; sabotage/arson by rival business owners wishing to destroy the 
secondhand clothing industry; a dispute between the market «owner», who collects rent from stallholders and his tenants; and/or corrupt government-official-sponsored arson intended to obtain the land so it could be sold to developers ${ }^{2}$. Gikomba traders claimed that a gang of arsonists set the fire and battled with market guards and sellers who tried to fight it. The Nairobi fire department's single engine arrived two hours after the fire began but had no reliable water source, so their efforts proved ineffective. The resultant catastrophe was profound for the thousands whose livelihoods depended on Gikomba.

\section{Heightening Class Differences as Trader Policy in the 1940s: Population Controls}

7 As apocalyptic as this fire was, to the point that it made the international news, it is vital to set it in context, which goes back to the 1940s and 50s, before Gikomba was founded during the 1970s, which is distinctly political. Two elements helped to generate negative policy toward small-scale traders at that time: efforts by African shopkeepers, who objected to competition from hawkers, and government policy that intentionally privileged certain traders at the expense of others. The shopkeepers, in the form of the East Africa Traders Association, wrote to the Nairobi Acting Town Clerk in April 1942 urging tighter restrictions on the granting of hawkers' licenses saying, «the majority of hawkers obtain licences to cloak various nefarious happenings» ${ }^{3}$. Such class differentiation among traders was regarded as desirable by policymakers, who intended not only that African shopkeepers be male and better capitalized, but also that some male traders become shopkeepers. Gendered class formation was a conscious aim of British administration. Thomas Colchester, the Nairobi Municipal Native Affairs Officer, stated in the 1941 Annual Report,

The aim is to evolve a class which will, with a little capital, be able to supply more people at lower prices... [T] he native hawker is usually a Kikuyu from 60 to 70 miles away taking advantage of temporary booms to earn Shs. 25/- to Shs. 30/- a month by 3 or 4 hours work a day. He usually lives in the most overcrowded parts of Pumwani and rarely has his wife or family with him. What is desirable is a more stable figure living at a higher level of subsistence and more knowledgeable in his trade.

Why did such people come to Nairobi? The pay from hawking was better, he said, than either rural or urban laborers' pay, and the war had caused a jump in the prosperity of the town ${ }^{4}$.

9 The British government, in its anxiety to diminish the possibilities for organized Kenyan resistance to colonial rule, and to maintain the profits of «legitimate» larger scale non-African owned businesses, also instituted ever more stringent population control measures in Nairobi after World War II. During and after the war Nairobi's African population skyrocketed, from 41,000 in 1939 to 70,000 in 1941, for instance, despite laws aimed at keeping most Africans out of Nairobi. Many of these sought to earn a living through hawking various commodities, especially foodstuffs, often from illegal locations, which included everywhere except the very few African markets allowed. Licensing traders became a chief means for controlling the burgeoning numbers of hawkers 5 . 
10 If in rural areas the authorities wished to discourage hawking since it constituted an alternative for Africans to labor on settler farms, in Nairobi urban administrators were increasingly concerned about simply keeping control over a growing bumptious trading population. The most important shift in government policy in the early $1940 \mathrm{~s}$ was that it was agreed that trading licenses, «which were at present only a revenue producing measure should be a control measure [emphasis mine]» ${ }^{6}$. This decision was evident in the 1941 Nairobi Annual Report, which stated, «With a view to limiting the native population and particularly the prostitutes, passes are now being issued for permanent residents in the town and the number of hawkers' licences is to be reduced from 500 to a maximum of $300 »^{7}$. The lower number of licenses did not accommodate most of the hawkers; Mary Parker estimated that in 1942 there were 470 itinerant hawkers, 225 traders, 145 shopkeepers, 150 proprietors of eating houses, 280 skilled artisanal workers, and 235 service workers among the self-employed African population of Nairobi. Women seem to have been mainly omitted from these figures, as were the hundreds of Kiambu hawkers who traveled into Nairobi daily8. While the Nairobi Municipal Council was not willing to forbid hawking altogether, it adopted the policy of gradually widening the number of commodities that required licenses to sell 9 .

11 Neither the underground economy nor the militancy of hawkers disappeared at the end of World War II, when the internal socioeconomic crisis became more evident - and acute, resulting in part in an escalated hawker war. At this time the colonial authorities pioneered against hawkers population control measures later employed during the Mau Mau Emergency. Their ever more stringent efforts included a February 1946 ordinance that allowed any authority to remove any African from the Municipality for any reason without warrant or appeal. In 1947 disorder was rampant in Pumwani and Shauri Moyo, and the trade licensing officer said that without more help he could not control increased trading activities involving more than 2000 unlicensed traders ${ }^{10}$. Thomas Askwith, the Native Affairs Officer, acceded to the Native Advisory Council's request and forbade granting trade licenses to women in 1945. This ruling was cancelled, however, due to a protest from «porige sellers» and the hardship imposed on urban women. The Nairobi Native Advisory Council agreed that the restriction was only to apply to women coming from the Reserves, and made so many exceptions for uji [English=porridge] sellers, who were supplying most African workers with their meals, that the prohibition became meaningless. The result of these conditions was another rash of laws in 1949 attempting to control both hawkers and voluntarily unemployed persons ${ }^{11}$. Under a 1942 Nairobi «spiv» law, 200 persons a month were picked up and deported to the reserves as vagrants in $1949^{12}$. By the late 1940s legal restrictions on marketing foodstuffs and traders' movements were such that most urban Africans were dependent on the underground economy, chiefly produce hawked by women from Kiambu and Thika, a growing town some twenty miles north of Nairobi. One observer of the scene in 1950 commented,

If one of the happier pictures of colonial Africa is that of the District Officer and

local chief proudly surveying a cotton crop or a new village well, the most gloomy is that of the police of East Africa harrying the vegetable sellers, usually women, on a periodic roundup of unauthorized markets in an urban estate ${ }^{13}$.

The criminalization of the ordinary activities of petty traders was well established by colonial precedents before the Emergency, and traders responded accordingly. Urban traders were, as Elkins stated, a chief target of the «complex, apartheidlike set of laws dictating among other things where Africans could live, where and when they could 
move, what crops they could grow, and what social places they could frequent», and, I would add, where and what they could sell, and their lack of access to banking services and well located permanent selling premises ${ }^{14}$.

\section{Colonial Markets and the Mau Mau Emergency}

13 The struggle over and in urban markets was a key element in the 1950s Emergency declared by the British to fight urban and rural guerrillas. Both rural and urban markets in the Nairobi area played a key role, a role recognized by the colonial government, which took steps to remove the perceived threats presented by insurgency at these markets.

14 In Kiambu, the area adjoining Nairobi immediately to the north and west, the colonial authorities took immediate measures to insure their control of markets, which could serve as meeting places for the Land and Freedom Army (LFA), called Mau Mau by the British. Kiambu was involved in the 1950s freedom struggle early on (LFA oathtaking there first came to the attention of the authorities in 1950, when it was declared illegal) $)^{15}$, but rural markets did not serve the purposes of freedom fighters well in the 1950s. Government authorities found these trade centers easier to control than the dispersed homesteads, while prosperous African and Asian shopkeepers were viewed as likely collaborators with the regime. Markets were raided by the LFA and a few shopkeepers killed ${ }^{16}$. Shopowners also had to worry about the other side. During the Emergency loyalist Homeguards hung around the markets, sometimes vandalizing the shops of those they viewed as Mau Mau sympathizers. The existence of smaller markets and isolated shops worried the authorities lest their shopowners be helping Mau Mau; they were routinely closed down. In the late 1950s when markets were allowed to reopen, loyalists got preference in license allocations; ex-LFA members or detainees were denied them ${ }^{17}$.

15 If rural markets lost their function as a political gathering place for men under the Emergency, with shopkeepers suffering persecution from both sides, urban markets became focal points for African political action, their volatile crowded spaces providing solidary anonymity. A number of factors helped make the Land and Freedom movement an urban phenomenon as well as a rural one. Among them was discontent with the Nairobi trade infrastructure. Nairobi had a critical shortage of market space; yet, rather than improving it, further constriction was caused by the application of Emergency regulations. For instance, in 1951 the structures at Shauri Moyo Market were quite dilapidated, but they were required to accommodate traders evicted from verandahs along River Road. In July 1952 there was an attack on the Master of Municipal Market, which was then raided twice by the police to arrest illegal African traders. A successful two-day boycott of vegetable supplies organized by the vegetable traders ensued. The mayor of Nairobi was then forced to negotiate a settlement to stop $i^{18}{ }^{18}$. The traders were clearly fed up with such harassment and organizing to resist.

16 If the immediate cause for the imposition of the Emergency was the assassination on 7 October 1952 in Kiambu of Chief Waruhiu, a Local Native Council member, the urban variation on the same theme was the assassination of Tom Mbotela on 27 November 1952 near Burma Market. Mbotela was a Nairobi African Advisory Council member popularly considered to be an arch-collaborator with the colonial regime. Burma Market had accommodated displaced traders from Shauri Moyo Market, which was 
undergoing renovations involving permanent construction in stone. As a result of the assassination, the police raided Burma, finding it «ramshackle», arrested all of the traders and took them to Kingsway Camp for interrogation. Two hours later a fire broke out at the market, widely supposed to have been set by Homeguards, which razed it completely. The opening of the renovated Shauri Moyo was then moved up from the eighth to the first of December ${ }^{19}$.

Kariakor ${ }^{20}$ Market was also thought by authorities to be a «black spot» and a gathering place for «spivs» and thugs. Spiv was a British administrative acronym for Suspected Persons and Itinerant Vagrants, and was applied pejoratively to traders, as was «drones» ${ }^{21}$. In May 1953 the police raided it, destroyed some 600 temporary market stalls at its rear, and arrested the occupants. Later that month they tore down illegal stalls at Shauri Moyo. Traders at Shauri Moyo and Duke Street experienced frequent police raids, arrests, and detentions. The worst impact on traders, however, was clearly made by Operation Anvil, which began on 24 April 1954. Caroline Elkins has described the significance of Nairobi for colonial officials and the magnitude of this operation, the largest British counterinsurgency effort, which summarily removed thousands of Kikuyu, Embu and Meru from Nairobi to concentration camps. Most of the traders came from these groups.

Nairobi was the linchpin in Britain's military campaign against Mau Mau...There was an unusual consensus in the ranks of both the military and...civilian government that the colony's capital was the nerve center for Mau Mau operations. Nearly three quarters of the city's African male population of 60,000 were Kikuyu, and most of these men, along with some 20,000 Kikuyu women and children...were allegedly [Mau Mau supporters.]... They were purported also to be perpetrating a host of other crimes, including armed robberies, the intimidation of witnesses, the levying of 'protection money', and the organization of boycotts of government-run buses and European products ${ }^{22}$.

In 1954 both Kariakor and Shauri Moyo were closed down completely at various points $^{23}$. The demolitions, closures and arrests were a response to the various violent incidents centering on markets and municipally owned shops. Officials said that Mau Mau terrorists were carrying out a campaign of intimidation and had instituted a type of protection racket aimed at Asian and other non-Kikuyu shopowners. The Duke Street Market was also burned down on 13 August 195424. Two Homeguards were killed at Kariakor on 21 January 1955. Despite a demonstration organized by loyalist Kikuyu traders against the murderers, all Kikuyu-, Embu- and Meru- (called KEM by authorities) owned shops were closed down for three months as a result. Armed LFA raids on municipally owned dairies and butcheries resulted in their closure ${ }^{25}$.

\section{Traders Organize to Resist}

19 Conflicts between hawkers and authorities were at the heart of the urban incarnation of the Land and Freedom Army movement in the 1950s. In Nairobi, as Onstad noted, «petty traders were natural recruits for [the LFA]: most of them had a strong impetus to fight the colonial government while their livelihood gave them a perfect cover for subversive activities.» By 1952 when the Emergency was declared, both rural and urban traders had organized to dispute various ordinances aimed at controlling their activities. Early 1940s attempts at organization were small scale; in 1942 there were cobblers' and banana sellers' guilds with about eighty members each, for instance ${ }^{26}$. But 
by the late 1940s large-scale organizations were forming to protect traders' interests. The United African Traders Association protested the proposed 1949 Verandah Trading By-laws, which prohibited conducting business on the porches of houses except in Asian areas, and the anti-spiv measures. The chairman, Kigondu wa Machira, met with the Town Clerk and Labour Officer and informed them that his organization had 4000 members in twenty branches, including mostly male-dominated occupations such as tailors, shoemakers, painters, charcoal sellers, tinsmiths, blacksmiths and vegetable dealers. Despite widespread administrative support, the Verandah Trading By-laws were dropped when the Solicitor General advised against the feasibility of outlawing this method of trade. Kamba women traders may also have been organizing themselves into dancing troupes at this time ${ }^{27}$.

The colonial administration responded by stepping up repression of traders. During the Emergency the colonial administration turned its attention to controlling hawking in Nairobi by drastically reducing the number of licensees, a measure also encouraged by loyalist successful traders, which became a key element in countersurgency efforts ${ }^{28}$. From 1952 to 1957 the number of uji (sold by women) licenses stood at 105, but the total number of hawkers' licenses fell from 667 to 185 . From 1953 to 1954 alone the number dropped by $400^{29}$. The cheap provisioning of workers was the chief argument used to preserve this number, which was not affected by Operation Anvil. This argument did not save the KEM tea hawkers, however, who were usually among the more prosperous male traders. They were forbidden to sell completely in 1953 because they were thought to be witnesses or accomplices to Mau Mau crimes, who refused to inform the police $^{30}$. Forging a hawker's armband was made a criminal offence when several people tried it. Hundreds of people were arrested for hawking without a license or hawking outside of permitted areas. People were even arrested for picking flowers, sorting over garbage, and spitting. Fences were built around African locations and curfews enforced. There were shortages of commodities like charcoal and sugar due to movement restrictions on traders. Spot raids were conducted to catch violators of the many restrictions and squatter villages like Kariobangi were destroyed ${ }^{31}$.

21 After the most violent part of the Emergency died down the authorities decided to crack down further, even on uji sellers; in 1958 only eighty uji licenses were given and in 1959 only sixty ${ }^{32}$. When a group of widows appealed this reduction, the Chief Municipal Inspector of markets gave them short shrift, saying, «all unlicensed hawking must stop and the offenders will be relentlessly prosecuted until that end is achieved. It is therefore necessary for the widows... to take up some form of livelihood that is lawful.» Former licensees got nowhere upon appeal. The General Secretary of the Nairobi People's Convention Party complained to the Town Clerk about the arrests of women hawkers, who were given Sh.50 fines or two months in prison. Other protests focused on a new policy dictating that itinerant hawkers could only sell in their own racial areas $^{33}$. For most women traders licenses, infrastructure and the bribes necessary to get them were in any case too expensive, nor were they granted licenses in rural areas when the few who could afford it applied to the African District Council ${ }^{34}$.

The articulated goals of government policy aimed at obliterating the hawker population concerned the security risk (with particular attention to the fact that most traders were Kikuyu), the presumed unsanitary methods of operation for cooked foods, general dirtiness, traffic congestion, the nuisance of traders' importunities to European housewives, and their assumed involvement in crimes more serious than the 
elementary one of illegal hawking. According to Muthoni Likimani, Europeans perceived women traders during the Emergency as being, "dirty Mau Mau savages.» Another argument, joined into by prosperous African traders, involved hawkers posing unfair competition for shopkeepers. There was also anxiety about the possibly dangerous political consequences of poverty. The 1954 Kenya government Report on Destitution said,

The tendency to reduce the numbers of open-air traders may make a contribution to the number of indigents. Questions of hygiene, traffic problems and no doubt many other factors induce the desire in those responsible to impose severe limitations on the numbers of African petty traders, but we would nevertheless urge that the opportunity of a modest livelihood that these activities afford should be provided whenever possible ${ }^{35}$.

This recommendation was ignored by the authorities whenever possible. Government persecution of hawkers, as well as the more general KEM removal policies such as Operation Anvil, usually most negatively affected vulnerable women and their children. For example, because a married woman's right to live in Nairobi was contingent upon her husband's status, she was automatically removed along with her husband. A letter of 28 April 1956 from Wangui w/o (wife of) Chege, a woman shopkeeper, to the Nairobi District Commissioner shows what could happen. She was left to watch her husband's shop for him after he was repatriated. She complained that the Ngara chief Owiso was harassing her in saying that she had no right to sell. But, she asserted, she was respectable, always paid the rent, had an official pass allowing her to stay in Nairobi, and four children to support.

Whilst I maintain my loyalty to her Majesty's Government I feel extremely injustified [sic] by Chief Owiso's action against me. Had I been a woman without proper standings and left to roam in the town then his actions would be justified and fair, however he is on the contrary and has no mercey [sic] upon my future being together with my children. It is not the intention of the government to make the women poor and I believe the Government is doing the best it could to see that the African women are advanced, but with [this] action it is to reverse our progress and stir hatred or bad feelings by misusing the Government Policy to the loyal citizens. I lay my trust on nobody but the British Government and I pray that Chief Owiso be stopped from his merciless actions on me.

The Nairobi District Commissioner (DC) told the Municipal African Affairs Officer that he was not going to reply to her as she had already been «repatriated» and was supposed to have gone with her husband in the first place ${ }^{36}$.

\section{Relaxation of Controls Surrounding Independence (1963): The Growth of Hawking}

By the early 1960s, the lifting of the Emergency restrictions on population movement allowed thousands of traders to go to Nairobi. By late 1956 the authorities had trebled the number of passes for individuals and vehicles to trade to Nairobi, while allowing many shops to reopen ${ }^{37}$. When the numbers of hawkers at Mincing Lane wholesale Market rose dramatically, the Nairobi City Council (NCC) Marketing Advisory Committee passed a resolution forbidding retail trade at Mincing Lane altogether, but to no effect ${ }^{38}$. Congestion there was extreme, with many hawkers selling uninspected produce less than 100 yards away ${ }^{39}$.

The Kiambu District Marketing Officer described the situation in 1960. 
The easing of movement restrictions and curfew has caused an absolute flood of uninspected produce into Nairobi in the form of baskets, headloads and even small handcarts. Hawking is rife within the City and this burden is being carried by legitimate wholesalers who continue to support Mincing Lane and have quantities of produce left over at the end of a morning. For this very reason some buyers are now not bothering to use the Market when produce can be delivered to the doorstep... [If the produce inspectors do not do something] in a month or two months, the market will be run by the African and Asian Traders not the City Council which to my mind is almost the position now. given (with the restriction that no hawkers were to be in the Central, a.k.a. European, city). Mincing Lane and City (formerly Municipal) Market traders asked for a reduction in stall rents, citing the hardships imposed by the granting of only 800 hawkers' licenses, a protest which illustrates the conflicting goals of organizations of legal stallholders and those of itinerant mainly illegal hawkers. A key political factor influencing the liberalization of license policy was the rising number of hawkers' organizations, formed by men in order to defend their interests. They organized both by market and generally ${ }^{42}$. Another was the colonial government's reluctant recognition of the inevitability of independence, fostered by their problems with keeping control. Africanization and politicization of the hawker struggle led to African politicians seeking hawker support with relaxed controls. In July 1960 over 400 trading licenses were issued, and in November over 800. The first African mayor of Nairobi, Charles Rubia, made the granting of more hawkers' licenses a priority in 1962, despite the fact that 1500 had already been issued in August. Nevertheless, illegal hawkers still predominated - by 1963 over 2000 of them. Most of the unlicensed sellers dealt in prepared foods; many were women ${ }^{43}$.

mid-1961 administrators felt that the situation was completely out of control. The 1961 Nairobi District Annual Report noted the dramatic increase in hawking and in the number of illegal markets, called Uhuru (Kiswahili=freedom) markets, but said that the authorities had decided to tolerate them because the government was unwilling to use the «last tier» of Emergency legal powers to do $\mathrm{so}^{44}$. Three major hawker organizations were formed between 1960 and 1962 and fought to obtain legal permanent or itinerant selling space. Onstad described the situation cogently; by mid-1961 it was «as if defeated Mau Mau had risen from the ashes, phoenix-like, in the form of militant hordes of petty traders.» Their agenda included not only the right to secure selling space of their choice, but also an increased number of licenses, relaxed regulations to allow permanence and expansion of businesses and capital accumulation, and the cessation of police harassment ${ }^{45}$.

As effective as the written petitions and protests were the boycotts of designated trading locations, protest marches, and the constant street fights in which bystanders 
came to the aid of hawkers resisting arrest. A typical case from the Crime and Incident Reports occurred on 8 July 1960 when police constables from Shauri Moyo were attempting to arrest illegal hawkers at Machakos Country Bus Stop. The police were stoned by the crowd, only succeeded in arresting one juvenile, and had to send for reinforcements to extract themselves from the imbroglio. Three incidents on 16 November 1960 at Shauri Moyo Market included one in which a large crowd prevented two plainclothes officers from making an arrest by pushing them out of the market, one being bitten on the finger, and two incidents in which police were stoned by the crowd. Machakos Country Bus Stop became notorious for its rowdiness ${ }^{46}$.

By the end of 1962 the Nairobi City Council had given up on trying to stop hawking altogether and instead hoped to control it somewhat. In the scramble in 1963 for new bylaws aimed at controlling hawkers (the old ones were invalidated by the court in 1962 as not applicable to itinerant hawkers and too general), the old ones were inadvertently repealed with no new ones yet passed, and governmental disarray was complete $^{47}$. The Nairobi Assistant Commissioner of Police wrote to the Permanent Secretary for Local Government, «To be perfectly honest, the Council have got themselves into such a mess in connection with hawking that it is really immaterial what amendments are made to the By-Laws», while the latter informed his Minister, «Unfortunately, like many problems, [hawking] has been allowed to grow because it could only have been solved by colonial/imperialist methods and these were becoming less and less appropriate as Uhuru drew near $»^{48}$. The remaining British officials might have been somewhat maliciously satisfied that Kenyans were having as much difficulty establishing control as they had had. Although the bylaws were reinstated, this situation serves as a symbol of the inadequacy of colonial hawker policy under the onslaught of postcolonial conditions. Arson, however, as a common event had subsided during this period with a conscious effort not to emulate harsh colonial methods.

\section{Post-independence Harassment of Traders and Arsons: Hawker Wars}

30 Can we say, then, that post-independence government policy improved, or has the criminalization of the informal sector and of government actions continued? The late colonial period in which the colonial government used legal and extra-legal methods to intimidate and damage traders and hawkers has distinct parallels with the period of the late 1980s to the present. The same two primary forces, mercantile and government interests, pushed trader policy and implemented crimes against hawkers to achieve their ends in the later period. However, the 1980s did not begin with the declaration of a hawker war and followed the 1970s, a period of relatively benign accommodation of trader and hawker interests. President Daniel arap Moi assumed office peacefully in 1978 at Jomo Kenyatta's death and seemed bent on pursuing the same erratic course of his predecessor's government: arrests and demolitions, not always sanctioned by the Nairobi City Council, combined with an effort to help some traders. To some he was a defender of the common people (Kiswahili=wananchi), more sympathetic than Kenyatta, who dismissed the poor as ragai (lazy or useless).

31 Government help translated the recommendations of a 1974 ILO Report to promote the informal sector into gendered applications that included measures taken to help jua kali (English=hot/fierce sun), artisans forced by poverty to work in the open air. Although 
women traders are more often without sheltered space and in the sun, the term jua kali has been applied only to male manufacturers, with occasional gestures toward the garment industry ${ }^{49}$. Police harassment of sellers was supposed to stop. In the mid-1980s President Moi saw to it that neat metal sheds were built for such artisans at Kamukunji across the river from Gikomba. In 1987 a Small Scale Enterprises Unit was established within the Ministry of National Planning and Development that emphasized helping manufacturers ${ }^{50}$. Although the ILO considered retail sellers to be a worthy part of the informal sector, the brunt of the conflicts fell upon them, most of them women traders, who still have more difficulties getting permanent selling space or pursuing legal trade.

The fortunes of the large dried staples trading population at Gikomba Market are emblematic of the situation for most women traders. Unlike most of Gikomba, the dried staples area was the object of repeated attacks by NCC police. In July 1988 the women, who had assurances from the District Officer and the local chief that they could build without molestation, constructed a handsome set of open sheds with metal roofs and posts to shelter themselves and their goods from the elements. This construction immeasurably bettered the whole appearance of the market. The women neatly arranged their open bags of staples on platforms beneath the sheds. It was a prime example of the positive virtues of following the Kenyan government slogan, harambee, self-help (translated by the cynical as help yourself). In mid-August the NCC police came and without warning demolished the whole, purposefully destroying pieces of metal roofing to prevent their reuse.

The arbitrary strictures of the authorities, riven by the conflicting goals of different parts of the government, understandably bewildered this trader at Gikomba in 1988.

Here we had built shelters against the sun and the rain, but they've been demolished. That's why we are suffering. At first [the chief] told us to demolish them. Then he told us to move down there to the vegetable sellers' place [by the Nairobi River]. The vegetable people had nowhere to go, but he told us to go and squeeze in. We refused and went to the member of Parliament for this area, Maina Wanjigi; he told us to stay. After that the chief told us that we should not construct anything; we should stay in the sun. I don't know why, and I don't know much ${ }^{51}$.

The permanent, often more flimsy, structures erected by other sellers were left unmolested; this differentiation in treatment had occurred repeatedly. In November the women composed a praisesong for President Moi and sent a delegation to ask him for permanent selling space, an effective route to success for those whose political support is perceived as being important ${ }^{52}$. However, the women did not succeed. While grassroots rural women's self-help efforts are lauded as promoting development, poor urban women have had their activities disrupted and their painfully earned infrastructure destroyed.

In December 1987 there were at least four raids by plainclothes police on a group of River Road streetside staples sellers, who suggested that the police wanted their confiscated goods for Christmas, while nearby storeowners encouraged the raids to discourage competition. One trader said that in 1986 the adjacent storekeepers had each paid Ksh.1000 to have them removed and that sometimes the police came six times a day. Elsewhere several of the more established market stallholders complained about competition from hawkers, one man calling them prostitutes ${ }^{53}$. In 1988 the major battle over turf again involved central city areas. A Mathare Valley protection scheme reputedly existed involving payments to KANU (ruling party) youthwingers of Ksh.5 
per month to secure freedom from NCC harassment of traders, but poor women selling on the streets in the central city had no protection.

A broader view of the impact of police harassment on traders comes from Winnie Mitullah's 1988 survey of 425 street traders, who gave the following reasons for not having licenses: ignorance of licensing procedures (55\%); failure of attempts to get one (13.1\%); illegal sites or activities making licensing impossible (15.6\%); and not affordable (12.6\%). Police harassment occurred daily or weekly for $54.2 \%$ of them, monthly for $24.4 \%$, and occasionally for $21.3 \%$, while $68.4 \%$ said that the harassment was because they were unlicensed. In $94.9 \%$ of the cases the harassment was by the NCC police, $3.5 \%$ by KANU youthwingers. The consequences for most traders of the harassment were that they had their commodities confiscated, but $8.2 \%$ were convicted of trading offenses, $4.5 \%$ paid bribes, and $2.7 \%$ had their structures demolished. Mitullah claimed that there were about 25,000 hawkers who were always at war with the authorities ${ }^{54}$. A riceseller at Ngara said that she had been caught three times by the police with illegal rice from Mwea. The first two times the police confiscated the rice but then sold it for her and gave her the money because they were sympathetic about her need to pay her son's school fees. The third time was not the charm; the rice was confiscated and she gave up on it. A woman pineapple seller resorted to hiring a man to grab the pineapples and run if the police appeared ${ }^{55}$. At one location a group of street sellers were raided so often that half of them disappeared within a week, only the younger, hardier and more desperate remaining.

Dried staples sellers are caught in a legal impasse in which feeding Nairobi efficiently is least considered. The Deputy Town Clerk in 1988 said that they fell into a «funny» category and could not be licensed under the bylaws as vegetable sellers, that the Gikomba sellers contravened the rule that sellers were not to be within 440 yards of a roadway, and that various pressures - from politicians, business owners, the mass of the unemployed - made for a balancing of interests between inside legal and outside illegal traders ${ }^{56}$.

38 A key point in the steadily mounting anti-hawker campaign came in October 1990, when all central city illegal markets were bulldozed. Divisions within the government and public discourse were evident in the events leading up to the destruction. In February 1988 the chairman of the NCC toured Gikomba promising better garbage disposal, while in June 1990 the Minister of Local Government ordered no more squatter settlement or hawker demolitions. The Nairobi independent newspaper, the Daily Nation, ran a feature article on unemployment on 10 October 1990, six days before the massive destruction, while the NCC planned to open five new open air markets to accommodate hawkers ${ }^{57}$. However, on 11 October 1990 at Machakos Bus Depot 300 NCC police took on hawkers with teargas and batons and were met with active resistance including: stonethrowing from residents of an adjacent estate; hawker-constructed barricades; a bonfire lit to disrupt traffic (successfully); and fisticuffs. Most business in the central city stopped and the situation was not gotten under control until late in the day, when armed groups of NCC police still patrolled, presumably to stop «the few shabbily dressed crafty hawkers who were trying to sell vegetables and fruit on the streets to homeward-bound workers.» On 16 October Gikomba was bulldozed and other illegal markets destroyed ${ }^{58}$. The impact of the destruction was major; traders roamed seeking temporary places to sell. It seemed that illegal selling was no longer an option for most and the days had returned when the goal of government was to annihilate 
trading as an option for indigent urbanites. Increasingly only the relatively wealthy could trade; traders themselves showed economic, gendered divisions. A successful male trader in 1988 told Eric Onstad, «The genuine trader is in a shop. The hawkers we see now, they are not in business; they are just getting something to eat $»^{59}$.

The ferocity of this attack was clearly linked to political causes. In Nairobi in July 1990 there were demonstrations centering in congested areas near or on the site of some illegal and legal markets (Kamukunji and Kawangware, for instance). These became riots when the demonstrators were attacked by the police and achieved international notice since they involved supporters of a multiparty political system, whose leaders had been imprisoned ${ }^{60}$. Kinuthia Macharia analyzed massive 1980s and 90s slum demolitions carried out in Nairobi from an ethnopolitical point of view, pointing out that the destruction of predominantly Kikuyu residential areas at Kamukunji (Muoroto) and Kibagare, which were heavily involved in the multiparty movement, resulted in the displacement of over 40,000 people. Wanjigi protested the demolitions, calling it another Operation Anvil, which cost him his position as Member of Parliament and his membership in KANU ${ }^{61}$.

News photos showed exclusively male hawkers battling police in October 1990. Some men fought but the majority of traders fled, trying to save as much of their property as possible. One woman cried as a bulldozer took down her stall, for which she had just paid Ksh.10,000 to the market committee ${ }^{62}$. Several women said that bankruptcy was the result of such attacks, and, on occasion, physical harm. The situation was worsening, not just at Gikomba. A pregnant woman was seriously injured in a stampede of people waiting to get forms to apply for NCC kiosks. Attempts to organize a queue failed and a barred door was also broken in the rush, while officials extended the deadline for handing out forms, giving out more than planned. Some of the kiosks were mobile and cost approximately Ksh.15,000; others were stationary at a cost of Ksh. $10,000^{63}$. Women sellers had particular difficulty raising capital to obtain NCC-allocated stalls, which cost Ksh.16,000 (or approximately \$940) in 1988, plus an unspecified amount in bribery (at least five years of an average Kenyan's income) ${ }^{64}$. Esther Wanjiru Kamau, the subject of a Daily Nation article, had her kiosk home demolished without warning. She was getting by - doing casual labor in the chief's office and selling greens and other foodstuffs from the kiosk - for which she had been paying an annual rent of Ksh.450 to the Ministry of Works. In an accompanying photo she was glumly sitting on the wreckage with her ten children and a grandchild, all of whom she was supporting ${ }^{65}$.

The immediate response of the women whose stalls were destroyed in 1988 was to seek the use of political influence - a patron to protect them. Thomas noted in 1985 that there was growing pressure on these groups to contribute money for political purposes; they were being forced into politics ${ }^{66}$. Even itinerant hawkers were organizing. In March 1989 over 300 women hawkers, typically aged thirty or more and the sole support of their families, marched to the Nairobi Provincial Commissioner's Office to protest constant harassment by the askaris [English=police]. Upon being denied entrance to the Provincial Commissioner's office and that of the Director of the City Inspectorate, they blocked the County Hall entrance until the Director came out to talk to them. He agreed to issue all of them hawkers' licenses, but at a rate which they refused as too high. One woman shouted, «We sell our vegetables from estate to estate and we make too little income to meet the licence fee!» Photos accompanying the article showed women, some aged in their sixties and seventies, with arms raised 
militantly ${ }^{67}$. In early 1992 a group of elderly Kikuyu mothers of political prisoners took refuge in Nairobi Cathedral after an Uhuru Park protest that included a hunger strike was attacked by police. In support the hawkers at Gikomba and Machakos Bus Stop instigated a boycott that became a riot $^{68}$.

Thus, in the 1990s the two forces of moneyed interests and the government worked together, just as the police were called on regularly by 1980s shopkeepers to remove the street traders in front of their shops. The struggle again was a gendered embodiment of conflicting class interests. Indeed, if the 1990s were marked by continual attacks on traders in various locations, in 2000 the crime of arson emerged again as a tactic in an ongoing war on traders. The more immediate context for the burning of Gikomba in September 2000 includes, for instance, a strong attack on 4 March, 1999, when two truckloads of NCC askaris demolished a large section of Gikomba by pulling down stall structures between $10 \mathrm{pm}$ and $3 \mathrm{am}$ the day after a fire razed timber stalls, furniture workshops and secondhand clothing stalls. The Daily Nation's account said that a dispute between a former market chairman and stallholders led to the attack. Traders said that,

they were being evicted to pave [the] way for modern stalls. The man, they said, was soliciting for Sh50,000 from people he wanted to allocate stalls [sic]. He had collected more than Sh20 million, they claimed. The chairman of the market, Mr. Daniel Macharia Kuria, said they had filed a case to block the eviction. «We had met the town clerk and the director of the city inspectorate to discuss the two-year-old row. They assured us that the demolition had been suspended for the matter to be solved,» he said. Mr. Kuria said the action had deprived many families of their livelihood. Bondeni Ward Councillor Kenneth Irungu, who led the demonstrators to City Hall, said the action was «barbaric». At City Hall 10 representatives of the traders and Councillor Irungu held a two-hour meeting with Mr. Mbugua and Mrs. Wandera. Other traders were locked out. After the meeting, Mr. Mbugua said they had instructed the traders to go to Dagoretti [police station] and pick[up] their property. The mayor said the confusion had been caused by the three groups involved - the people allocated the land, stall holders and hawkers ${ }^{69}$.

The report nicely summarized the conflicting interests and class divisions among traders that made Gikomba vulnerable to lethal attacks in which poorer traders suffered the most.

The September 2000 Gikomba fire, in fact, followed a series of fires at markets in Nairobi and elsewhere in Kenya. The fires deemed newsworthy in 2000 before 6 September included: 8 February, secondhand clothes stalls at Nakuru (blamed on arsonists); 23 February, jua kali sheds at Thika; 18 March, Garissa open air market (arson); 6 August, stalls at Kisumu; and 21 August, complete destruction of Freemark Market at Uhuru Park in Nairobi ${ }^{70}$. The class nature of this hawker war became even more obvious in the events immediately following the 6 September fire. As in the 1950s, the Gikomba struggle became conflated with the increasingly violent politics accompanying elections. Agence France-Presse reported,

a riot [was triggered by the fire] among vendors, who said they suspected arson. Unrest spread to neighbouring areas, cutting off eastern and northeastern roads into the city. Police used teargas to battle against protestors wielding sticks, stones and other crude missiles. Witnesses said the situation got out of hand when opposition member of parliament James Orengo coincidentally arrived at the scene [at the same time as] a convoy with the body of an opposition activist who had been killed when police violently broke up a pro-reform rally by the MP on August 19 . Police had earlier banned attempts to transport the body from the city morgue to the victim's house in Kamukunji for an overnight stay, before it was taken to 
central Kenya for burial on Thursday. Finding a stand-off between the police and vendors, Orengo alighted to address the market traders, witnesses said. Fighting erupted immediately between police and vendors trying to break through to the city centre to attack shops owned by Asians, forcing even the MP to flee, witnesses said. The traders wanted to attack Asian-owned shops because they suspected city officials had allocated their market territory to Asian developers. Rioters also tried to march on City Hall, but were dispersed before the clashes finally died down on Wednesday ${ }^{71}$. kinds of government attacks had become so commonplace ${ }^{72}$. The police have often become predators regarding traders, as recounted in numerous stories told me by traders about extortion, and confirmed by my own observations and newspaper reports. For instance, in June 2000 three policemen extorted Ksh.50,000 from a trader on Kirinyaga Road in Nairobi ${ }^{73}$. Police methods routinely include torture of suspects, as reported by the U.N., using specific examples from Kiambu, and confirmed by oral sources ${ }^{74}$. Even the payments made by this researcher for research assistance had to be surreptitious in order to prevent local police discovering and extorting them from my assistants. This strategy sometimes failed in any case, so they were robbed.

\section{Government Responsibility: Reform?}

How far is the central government responsible for these arsons, assaults and robberies? The indicators are mixed regarding government involvement in market arsons. Since the importation of secondhand clothing was widely believed to be controlled by associates of President Moi, burning Gikomba's used clothing section made no sense in that regard. However, because NCC attacks on Gikomba have been long-term, unequivocal and vicious, traders' attribution of responsibility for the arsons to the government makes sense out of their palpable misery. After the 6 September fire Jane Wambui, a Gikomba trader, said, «Nobody was trying to put it out, there was no water. Some people were fainting, some people were crying. We can start again but we have no money...we are hungry, our children are hungry ${ }^{75}$. The rending conflicts over Gikomba pit developers, who want the land, abetted by corrupt government officials who sell them the ostensibly «public» land, against the majority of the traders, stallholders and hawkers, who lead increasingly desperate lives on the edge. Thus, speculation over the causes of the fire/s inevitably centered on, as one news report stated, «well-connected members of the species that has given capitalism in Kenya a bad name, the private developers, [who] had hired arsonists to destroy Gikomba so they could grab the land $»^{76}$. The fact that the fires (and the police attacks) mostly happen at night when they are least likely to be fought fuelled suspicions, nor did condolences from prominent government officials such as the Vice-President and the Minister of State allay them ${ }^{77}$. There was no official inquiry into the causes of any of these fires, furthering the belief that government either employed agents to start them or at the least condoned them.

The context for the 6 September fire also includes subsequent events: arson at Garissa Lodge Somali market in Eastleigh in Nairobi in December 2000, a fire that killed at least three people; and arson that destroyed Kangemi Market, a large legal market with hundreds of sellers in a Nairobi suburban slum ${ }^{78}$. In a case that seems to epitomize police actions toward traders, on 1 November 2001 a Gikomba secondhand clothes

Crime, Histoire \& Sociétés / Crime, History \& Societies, Vol. 11, n² | 2007 
dealer was robbed by a gunwielding gang of six men and taken to Aga Khan Hospital by a friend in his car, whereupon police stormed the Casualty Department and arrested him, having mistaken him for one of the gang who robbed him. In addition, two other traders were seriously injured by the gunfire as the robbers tried to escape. Police shot and killed two of the gang ${ }^{79}$. But there is a certain convergence of the activities of gangs and police. While some uniformed police may openly extort bribes (I observed more than one at this activity), others change clothes and form or join gangs at night to rob, assault and otherwise terrorize civilians-from the victims of carjackings to poor traders.

The sources of Nairobi crime are multiple, but the primary blame for it lies with the government, some of whose members have increasingly vitiated laws regarding sanctity of persons and property and felonious assaults by their routine contravention. In following the colonial pattern of criminalizing informal sector participation, the government has implemented crimes itself. Self-help has truly become helping yourself for some of the powerful and wealthy. Since self-help for the urban poor now requires informal sector participation, this collision course charted by a government set on profiting at their expense will only be conducive to more massive conflagrations of various kinds. The pattern of the 1950s seems now to be established once again, a pattern that led to the overthrow of an oppressive government at that time. The Moi government has now also been replaced, but corruption continues. Unless a radical economic restructuring fuelled by a refurbishing of moral sense takes place, it is difficult to see a way forward that does not involve even more drastic violence, both government-sponsored and not. Most people just want to earn a peaceful living and are only forced to violence when defending their livelihoods from what they see as unjustified impositions. In effect, whatever the laws governing traders, and whatever politicians say to hawkers at election time, government policy regarding traders has become the crimes of property theft and destruction, aided by assaults and robberies, and enabled by the criminalization of the traders' ordinary activities and the alliance between the government and propertied interests. Class warfare has become an ongoing phenomenon, expressed in this case most characteristically as arson.

So, after independence the new government drew on colonialist-introduced techniques to control trade and traders when it was expedient to do so, perpetuating vagrancy laws and antihawker, antisquatter policies. If occasional humanitarian concerns and perceptions of possible political benefit diminished the persecution in the 1970s, they never stopped it. Indeed, the oppressiveness of the system in which the police are struggling from an underprivileged position to carry out the wishes of the ruling class is intensified by its divisive effects. Government persecution of traders or squatters in effect supplements the pay of police, who have demonstrated against irregular pay ${ }^{80}$. The low pay or lack of pay for the police is a systemic problem that could be solved by cracking down on corruption up the line. Police abuses could be diminished by reforming the police to concentrate on service rather than control, while also reforming informal sector laws and policies to accommodate survival needs of the population.

Cooper has described the situation well.

Harassing squatters, beer brewers and prostitutes underlined the hegemony of the dominant class, whose orderly ways were made to appear legitimate, while the 'illegitimacy' of lower-class life was rubbed in by the humiliation of police raids. Such an urban policy might also preclude other forms of control, cooptation and 
legitimacy, and make more difficult the development of a hierarchy of privileges and incentives that would encourage a differentiated and respectable working class instead of a threatening urban mass ${ }^{81}$.

With government authoritarian tendencies exacerbated, immediate political considerations outweigh the necessity not only to provide employment but also to feed Nairobi. Harming the distributive system penalizes both traders and the general populace by undermining a cheap urban food supply. Criminalizing many survivaloriented strategies of an underclass makes it inevitable that they will break the law, and «seek by noncompliance and resistance to influence the state to change.» They have become adept at deploying what James Scott called «everyday forms of resistance» to defend themselves and their livelihoods against the depredations of various arms of the state ${ }^{82}$. The wellbeing of traders' families depends on them. Much of Gikomba was flattened early in 1987. It was rebuilt then, after the 1988 destruction, and after the 1999 and 2000 fires. The arsons continue, but so does the determination of those afflicted by them. A destructive cycle has been created involving class warfare and crimes sponsored by members of the propertied class and the criminalization of the informal sector, all of which mandates the immediate implementation of innovative reforms.

\section{BIBLIOGRAPHY}

Cooper, F., Introduction, in Cooper, F. (Ed.), Struggle for the City: Migrant Labor, Capital and the State in Urban Africa, Beverly Hills, CA, Sage, 1983.

Dickerman, C., Africans in Nairobi During the Emergency: Social and Economic Changes, 1952-1960, University of Wisconsin Department of History M.A. thesis, 1985.

Elkins, C., Imperial Reckoning The Untold Story of Britain's Gulag in Kenya, NY, Henry Holt, 2005.

England, A., Traders rampage after fire sweeps Nairobi market, Seattle Times, 7 Sept. 2000, A15.

Githongo, J., Who's Putting Traders Through a Test of Fire?, East African Standard, 15 Sept. 2000, p. 1.

Gray, K. R. et al., Entrepreneurship in Micro-Enterprises, Lanham, MD, University Press of America, 1996.

Hake, A., African Metropolis: Nairobi's Self-Help City, NY, St. Martin's, 1977.

Himbara, D., Kenyan Capitalists, the State, and Development, Boulder, Lynne Rienner, 1994.

International Labour Office, Employment, Income, and Equality: A Strategy for Increasing Productive Employment in Kenya, Geneva, ILO, 1974. Based partly on an earlier 1972 ILO Report.

Itote, W., Mau Mau in Action, Nairobi, Transafrica, 1979.

Kenya, Government of Commission of Inquiry Report 1955-1956.

Kershaw, G., Mau Mau From Below, Oxford, James Currey, 1997. 
Leo, C., Land and Class in Kenya, Toronto, University of Toronto Press, 1984.

Likimani, M., Passbook Number F. 47927 Women and Mau Mau in Kenya, London, MacMillan, 1985.

Macharia, K., Slum Clearance and the Informal Economy in Nairobi, Journal of Modern African Studies, 1992, 30, 2, pp. 221-236.

Mbilinyi, M., City and 'Countryside' in Colonial Tanganyika, Economic and Political Weekly, (26 Oct. 1985) 20, 43 , WS- 89.

McCormick, D., Small Manufacturing Enterprise in Nairobi: Golden Opportunity or Dead End?, Johns Hopkins University Department of Economics Ph.D. dissertation, 1988.

Mitullah, W. V.? Hawking as a Survival Strategy for the Urban Poor: The Case of Nairobi, Ford Foundation Report, May, 1990.

Muiruri, S., Berhe, A., Askaris Demolish Gikomba Market, Daily Nation,5 March 1999, p. 1.

Mungai, E., Thelma A., Kenya Women Reflections, Nairobi, Lear, 1983.

Mung'ou, T., Mystery Deepens as Traders Are Burnt Out, The Nation, 19 Dec. 2000a, p. 1.

Mung'ou, T., Year of the Mystery Market Infernos, The Nation, 30 Dec. 2000b, p. 1.

Noormohamed, S.O. Development Strategy for the Informal Sector: The Kenyan Experience, in Ndegwa, P.L.P. et al. (Eds.), Development Options for Africa in the 1980s and Beyond, Nairobi, Oxford University Press, 1985, pp. 186-193.

Okoko, T., Millions Go Up in Smoke as Fire Guts Huge Market, Africa News, 6 September 2000.

Onstad, E., Street Life: A History of Nairobi's Petty Traders and Their Organizations, 1899-1975, University of Nairobi Department of History M.A. thesis, 1990.

Parker, M., Political and Social Aspects of the Development of Municipal Government in Kenya, with special reference to Nairobi, Great Britain Colonial Office. N.d., c. 1949.

Robertson, C C., Trouble Showed the Way Women, Men and Trade in the Nairobi Area, 1890-1990, Bloomington, IN, Indiana University Press, 1997.

Ross, M. H., Grass Roots in an African City: Political Behavior in Nairobi, Cambridge, MIT Press, 1975.

Scott, J. C., Everyday Forms of Resistance, in Colburn, F. D. (Ed.), Everyday Forms of Peasant Resistance, London, M.E. Sharpe, 1989, pp. 3-33.

Smith, M. E., Introduction, in Smith, M.E. (Ed.), Perspectives on the Informal Economy, Lanham, MD, University Press of America/Society for Economic Anthropology, 1990.

Stren, R. et al., Coping With Urbanization and Urban Policy, in Barkan, J.D. (Ed.), Beyond Capitalism vs. Socialism in Kenya and Tanzania. Boulder, CO, Lynne Rienner, 1994. pp. 175-200.

Thomas, B., Politics, Participation and Poverty: Development Through Self-Help in Kenya, Boulder, Westview, 1985.

Throup, D. W., Economic and Social Origins of Mau Mau, Nairobi, Heinemann, 1988.

Tignor, R. L., Colonial Chiefs in Chiefless Societies, Journal of Modern African Studies, 1971,9, 3, pp. 339-359.

Warigi, G., Gikomba Fire: Who Are the Real Losers?, Daily Nation, 10 Sept. 2000, p. 1.

Werlin, H. W., Governing an African City, A Study of Nairobi, NY, Africana, 1974. 
Werlin, H. W., The Hawkers of Nairobi: The Politics of the Informal Sector, in Obudho, R.A. (Ed.), Urbanization in Kenya, Lanham, MD, University Press of America, 1983, pp. 194-214.

White, L., The Comforts of Home: Prostitution in Colonial Nairobi, Chicago, University of Chicago Press, 1990.

BBC News, London.

Daily Nation, Nairobi newspaper.

Deaths feared in Kenyan capital riots after market blaze, Agence France-Presse, 6 Sept. 2000. Dow Jones Interactive: http://ptg.djnr.com/ccroot/asp/publib/story_clean_cpy.asp?

articles=AFPR0025008819'INT.

East African News Review, Nairobi, 1948.

East African Standard, Nairobi.

$K B C$, Nairobi.

Kenya, Government of Commission of Inquiry Report 1955-1956.

Nairobi City Council. Report on Destitution, 1954.

Nairobi Fuel and Food Survey, 1957.

Kenya Times, Nairobi.

The Nation, Nairobi.

Weekly Review, Nairobi.

Interviews:

Askwith, T.G. 13 Oct. 1992.

Colchester, Thomas. 19 Oct. 1992.

Nairobi Area Traders. Interviews 1987-1988, 1990. Location of market named, informants numbered in references.

Njora, John. Nairobi Deputy Town Clerk. 2 Nov. 1988.

\section{NOTES}

1. Portions of this essay are based on findings in Robertson, 1997. An unrevised version was presented at the British East Africa Institute Crime in East Africa Conference, Naivasha, Kenya, July, 2002.

2. Okoko (2000); Warigi $(2000,1)$.

3. LG 2/125 Document 2, 22 Apr. 1942. In 1948 the first African businessman was appointed to an important trade advisory committee. MAA $8 / 22$ Chief Native Commissioner to Municipal African Affairs Officer 6 Jan. 1948. All call numbers refer to documents in the Kenya National Archives in Nairobi.

4. ARC(MAA) 2/3/8III: NMC AR 1941, 22; interview Thomas Colchester, 19 Oct. 1992.

5. LG 2/125 Document 2, 22 Apr. 1942; MAA 8/22 Chief Native Commissioner to Municipal African Affairs Officer 6 Jan. 1948; ARC(MAA) 2/3/8III: NMC AR 1941, 22; interview Colchester; Onstad $(1990,64)$.

6. LG 3/733 DC Nakuru to Commissioner for Local Government 16 Feb. 1942; MCI 6/881, Sixth Annual Conference of District Council Representatives 11-12 Sept. 1945. 


\section{7. $\mathrm{PC} / \mathrm{CP} 4 / 4 / 1,4$.}

8. Parker (n.d.), c. 1949, 20; DC/KBU 1/34 Kiambu AR 1943, 7. Parker also noted that there were 550 known traders in Kiambu, or about one for every sixty families, in addition to the hawkers.

9. LG 2/125 Doc.27, 1942 Amendment to Hawkers By-laws; MCI 6/881 Crown Counsel to Chief Secretary, Ministry of Commerce 2 Mar. 1945; African Affairs Dept. AR 1949, 57; Onstad (1990, pp. 110-111).

10. LG 2/125 Doc.27, 1942 Amendment to Hawkers By-laws; MCI 6/881 Crown Counsel to Chief Secretary, Ministry of Commerce 2 Mar. 1945; African Affairs Dept. AR 1949, 57; Onstad (1990, pp. 110-111).

11. MAA 8/22 Superintendant of African Locations to Superintendant C.I.D., 28 Oct. 1947; White (1990, p. 191); Mungai, Awori (1983, p. 166).

12. African Affairs Department, Annual Report 1949, p. 57.

13. Werlin (1974, 56-57); PC/CP 2/1/13 minutes Kiambu LNC 13-15 Mar. 1945, 9; NCC 27/10 DC Nairobi to Town Clerk 4 Oct. 1945; LG 3/3140 minutes NMC Native Affairs Committee 6 Jan. 1949; CS 1/14/11 minutes Nairobi Native Affairs Committee 15 Oct. 1945, 1; White (1990, p. 153); Throup (1988, p. 188).

14. Elkins (2005, p. 152).

15. DC/KBU 1/41 Kiambu AR 1950: 1; MAA 9/835. Governor's Order in Council 12 Aug. 1950.

16. LG 3/2434 Secretary of African Affairs to Secretary for Local Government, Health and Housing 11 Sept. 1957; Itote $(1979$, p. 140). Kershaw $(1997,250)$, mentioned both the notoriety that some Homeguards earned for their violence and extortion and that some gang members who carried out the Marige massacre were boys who hung out at Marige Market in Kiambu.

17. CS 1/14/33 minutes Kiambu ADC: 30 Oct. 1956; ARC/MAA 2/3/36VII Central Province AR 1953: 37; 1954: 24; LG 3/2700 minutes Kiambu ADC 29-30 July 1957: 7. LG 3/2434 Draft Minute Council of Ministers Nov. 1957; Permanent Secretary for Commerce and Industry with Secretary for Local Government, Health and Housing 19 Nov., 16 Dec. 1958; Commissioner for Local Government to Clerk Nakuru Town Council 29 Nov. 1958; LG 3/2701 minutes Kiambu ADC 3 Feb. 1956: 2; DC/KBU 1/45 Kiambu AR 1956, 30.

18. LG 3/3141 minutes NMC African Affairs Committee 25 Jan., 3 Oct. 1951; NMC AR 1952, 17, 23, 30.

19. NCC AR 1952, 18; East African News Review, 5 Feb. 1948; Onstad (1990, p. 104).

20. Kariakor was named for the World War I Carrier Corps; Kenyans were not allowed to carry guns but served as porters. Similarly, in Accra, Ghana, there is a neighborhood called Kariorkor, which also housed Carrier Corps recruits.

21. African Affairs Dept. AR 1952, 59; Mbilinyi (1985, WS-89) has an excellent analysis of the language applied to African urbanites in colonial Tanganyika.

22. Elkins $(2005,124)$.

23. LG $3 / 3143$ minutes NCC African Affairs Committee 6 May 1953; Finance Committee 18 May, 19 Oct. 1953; NCC AR 1953, 27, 38, 53; 1954, 44.

24. Nairobi African Affairs Dept. AR 1953, 157; LG 3/3144 minutes NCC African Affairs Committee 1 Sept. 1954. The origins of this legal market remain a mystery; it seems to have existed only in the early 1950 s and was not rebuilt.

25. NCC AR 1955, 2, 48; ARC(MAA)2/3/16IV Intelligence Report Dec., 1944; NCC AR 1953, 53.

26. Onstad (1990, 110); ARC(MAA) 2/3/8IV Nairobi AR 1942, 4; 2/3/8III NMC Native Affairs AR $1941,22$.

27. LG 2/281 Nairobi Municipal Verandah Trading By-laws, 1949; Kigondu wa Machira to Town Clerk 24 Aug. 1949; Labor Commissioner to Acting Commissioner for Local Government 21 Dec. 1949; Solicitor-General to Commissioner for Local Government 29 Dec. 1949. Rural traders were more represented in the Central Province African Merchants and Growers Association, which had 
political links to the Kenya African Union (later KANU, the present ruling party). DC/KBU 1/42 Kiambu AR 1951;4; African Affairs Dept. AR 1950: 5.1950.

28. Robertson (1997, pp. 130-131).

29. Onstad (1990, pp. 81-82); Dickerman (1985, pp. 37-39).

30. Ross (1975, p. 20).

31. NCC AR 1952, 12; 1953, 12; 1954, 12-15, 60; 1955, 12-16; Dickerman (1985, pp. 20, 38, 41, 18-19, 12); AA 13/1/8/9 Kiambu AR 1957, 1.

32. LG 3/3147 minutes NCC African Affairs Committee 12 Oct. 1957; LG 3/3149 minutes NCC General Purposes Committee 4 Sept. 1959.

33. NCC 27/10 Chief Municipal Inspector to Githuka s/o Kikuyu Feb. 1959; LG 3/3149 minutes NCC General Purposes Committee 6 Feb. 1959; LG 3/734 Salim Faraj to Town Clerk 17 Dec. 1959.

34. If we assume that the proportion of loyalists was the same among women as among men, then gender appears to have triumphed over political loyalty as a criterion for awarding licenses at Fort Hall, where women were refused them. CS 1/14/63 minutes Fort Hall ADC 9 Feb. 1954; 8 Nov., 16 May 1955; 8 Nov. 1956; minutes Fort Hall ADC Trades and Transport Committee 9 Feb. 1954; Government of Kenya, Commission of Inquiry Report 1955-1956, 44-45; CS 1/14/33 minutes Kiambu ADC Trade and Markets Sub-Committee 28-29 Jan. 1954, 1.

35. Werlin (1983, pp. 199-200); Likimani (1985, p. 65); Report on Destitution (1954, p. 5).

36. MAA $9 / 904$ corres. 28 Apr. 1956. Some of those who were returned to their supposed home districts had never lived there before.

37. DC/KBU 1/45 Kiambu AR 1956, 5; 1958, 1; Leo (1984, p. 62). Hake(1977, p. 58), estimated that by 1957 there was a shortfall in Nairobi housing of space for some 22,000 Africans, despite daily repatriations.

38. LG 3/3148 minutes NCC Marketing Advisory Committee 14 Nov. 1958.

39. Agr 4/69 Kiambu Monthly Marketing Report: 10 Apr. 1960; Fortnightly Reports 20 Apr., 5 May, 15 Sept., 2 Nov. 1960; 21 Jan., 6 July 1961; General Manager Central Province Marketing Board to Assistant Director of Agriculture Nyeri 10 Nov. 1959.

40. DAO/KBU 1/1/93 Kiambu District Marketing Monthly Report Feb. 1960; Fortnightly Report 18 Mar. 1959.

41. LG 3/2702 minutes Kiambu ADC, Marketing Report Aug. 1960; LG 3/3150 Resolutions NCC General Purposes Committee 16 June 1961; DC/KBU 1/46 Kiambu AR 1959, p. 3; Nairobi Food and Fuel Survey (1957, p. 59).

42. LG 3/3150 minutes NCC Finance Committee 21 June 1961; JA/LG 5/1 officers, Kariakor African Traders Association to Town Clerk Nairobi 28 Apr. 1960; AA 13/1/8/9 Nairobi District AR 1959, 20. 43. Minutes NMC General Purposes Committee 22 July, 4 Nov. 1960; Onstad (1990, p. 160); Werlin (1983, pp. 200-201); AA 13/1/8/9 Nairobi AR 1960, p. 17.

44. AA 13/1/8/9 Nairobi AR 1961, p. 3.

45. Onstad (1990, pp. 151-152, 166-171, 188-189). LG 3/3048 Kenya Auctioneers, Hawkers, Marketeers and Traders Union to Town Clerk 25 Oct. 1962; Nairobi Hawkers Traders Association to Prime Minister Kenyatta 4 May 1964; KAHMTU and Nairobi Vegetable, Fruits, Hawkers Traders Association to Governor of Kenya 5 Jan. 1963.

46. LG 3/3048 Inspector General of Police to Minister of Internal Security and Defence 16 Mar. 1964; Crime and Incident Reports, 1960-1964.

47. AA 13/1/8/9 Nairobi AR 1962, p. 4; Onstad (1990, pp. 158-159).

48. LG $3 / 3048$ Assistant Commissioner of Police Nairobi to Permanent Secretary for Local Government 17 Nov. 1962; latter to Minister for Local Government 2 Sept. 1963.

49. Gray et al., 1996; Himbara (1994, p. 93); McCormick (1988, p. 149).

50. Noormohamed (1985, p. 188); Situation Analysis II (1984, p. 46); Macharia (1992, pp. 230-231, 234); Stren et al. (1994, p. 179); McCormick (1988, pp. 78-79); Mitullah (1990, pp. 73, 75); Daily Nation, 12 July 1988. 
51. Interview 214 Gikomba: 16 Mar. 1988.

52. Interviews 241 Gikomba: 31 Mar., 22 Aug. 1988.

53. Interviews 142 Nyamakima: 7 Jan. 1988; S23 Shauri Moyo: 28 Mar. 1988; 54 Ngara: 23 Oct. 1987.

54. Mitullah (1990, pp. 15, 56-60, 72-73).

55. Interviews 82 Ngara: 2 Nov. 1987; 516 Wangige: 2 June 1988.

56. Interview Njora 2 Nov. 1988.

57. Daily Nation, 15 Feb. 1988, 16 June 1990, 2, 10, 16 Oct. 1990.

58. Daily Nation, 12, 17 Oct. 1990.

59. Onstad (1990, p. 283). When in 1998 we tried to use an open courtyard at the Gikomba Trades Union Congress offices for filming a market women's group, a manager drove us off saying, «This place is for workers,» implying that the women were beggars.

60. Weekly Review,13 July 1990.

61. Macharia (1992, pp. 230-231); Stren et al. (1994, p. 179).

62. Pers. comm. JNT: 5 Nov. 1990; Daily Nation, 17 Oct. 1990.

63. Daily Nation 27 Jan., 16 Feb. 1988.

64. Minutes NCC Education and Social Services Committee 5 Aug. 1988, 90.

65. Daily Nation, 27 Aug. 1988.

66. Thomas (1985, p. 180).

67. Kenya Times, 15 Mar. 1989. Some of the women were from an illegal central city market.

68. East African Standard, 5 Mar. 1992, p. 1.

69. Muiruri, Berhe (1999, p. 1). Unlike in earlier references, I have included the headlines here to show how widely the perception was shared that destroying Gikomba was a catastrophe of major proportions.

70. «A Tale of Calamity for the Country», Daily Nation, 7 September 2000, p. 1.

71. «Deaths feared in Kenyan capital riots after market blaze,» Agence France-Presse 6 Sept. 2000. Dow Jones Interactive, available at: http://ptg.djnr.com/ccroot/asp/publib/ story_clean_cpy.asp?articles =AFPR0025008819'INT.

72. KBC Nairobi: 6 Sept. 2000; England, «Traders rampage after fire sweeps Nairobi market,» Seattle Times, A15.

73. Daily Nation, 27 June 2000, p. 4.

74. Daily Nation, 26 June 2000, p. 8.

75. BBC News, 6 Sept. 2000, http://news.bbc.co.uk/low/english/world/africa/ newsid_913000/913202.stm

76. Githongo (2000, p. 1).

77. Warigi (2000, p. 1).

78. Mung'ou (2000a, p. 1; 2000b, p. 1).

79. «Gun-Wielding Policemen Storm Aga Khan Hospital», East African Standard, 2 Nov. 2001.

80. Daily Nation, 12 Dec. 1987, p. 1. They are, in any case, woefully underpaid. The situation resembles the pre-1930 tribute exaction by chiefly retainers, who were not paid a wage. Tignor (1971, p. 349).

81. Cooper (1983, p. 8).

82. Smith (1990, p. 69); Scott (1989, pp. 7, 9). 


\section{ABSTRACTS}

This article concerns the crime of arson at Nairobi (Kenya), which became common in the 1950s Mau Mau Emergency when the British colonial government was attempting to control a growing insurgent movement, the Land and Freedom Army, which used urban African markets as one of its key loci for organization. Many traders were involved in the insurgency and the government used arson to burn them out, before deporting most of them to the reserves in Operation Anvil. The constant struggle over urban space continued after Kenyan independence in 1963, when in the 1990s and later, in particular, arson once again became a key tactic used by corrupt government officials in alliance with developers to get control over prime urban land. The best example is the five-day Gikomba Market fire that destroyed most of it, but not the will of the sellers to rebuild. It is widely believed that the thugs who burned the market did so for hire. Thus, the class struggle continued, embodied in the crime of arson between a privileged class including high government officials and developers and an insurgent underclass bent on survival.

Cet article porte sur le crime d'incendie volontaire à Nairobi (Kenya), qui se développa dans les années 1950, au cours de l'insurrection Mau Mau. À l'époque, le gouvernement colonial britannique cherchait à contrôler l'essor de la Land and Freedom Army pour laquelle les marchés urbains africains représentaient un des principaux centres d'organisation. De nombreux négociants étaient impliqués dans l'insurrection et le gouvernement employait l'incendie volontaire pour se débarrasser d'eux, avant d'en déporter la plupart dans des réserves dans le cadre de l'Opération Anvil. La lutte constante pour l'espace urbain se perpétua après l'indépendance kenyane de 1963, en particulier lorsqu'à partir des années 1990, l'incendie redevint un instrument-clé utilisé par des fonctionnaires corrompus alliés à des promoteurs immobiliers cherchant à s'emparer des meilleures parcelles urbaines. Le meilleur exemple en est l'incendie du Marché Gikomba qui dura cinq jours et en détruisit la plus grande partie, sans pour autant briser la volonté des marchands de le reconstruire. L'idée que les incendiaires étaient stipendiés est couramment acceptée. De sorte que l'incendie volontaire incarne la lutte de classe persistante entre des privilégiés - comprenant des hauts fonctionnaires et des promoteurs - et une classe défavorisée révoltée luttant pour sa survie.

\section{AUTHOR}

\section{CLAIRE C. ROBERTSON}

The Ohio State University, Dept of History, 106 Dulles Hall, 230 West 17th Avenue, Columbus OH, 43210-1267 USA, robertson.8@osu.edu

The Ohio State University. Claire Robertson is Professor of Women Studies and History at the Ohio State University. She has published six books and numerous articles, among which Sharing the Same Bowl (Indiana U.P. 1984) has received the African Studies Association's Herskovits Book Award (1985), and Trouble Showed the Way. Women, Men and Trade in the Nairobi Area 1890-1990 (Indiana U.P. 1997), which dealt with small women traders in Nairobi, has suggested the issues discussed in this article. 